\title{
Bulletin of Hispanic Studies
}

\section{"The Fatal Fact of the Woman Writer": Transnational Encounters in the Avant-Garde Scene of Interwar Spain.}

\begin{tabular}{|c|c|}
\hline Journal: & Bulletin of Hispanic Studies / Bulletin of Contemporary Hispanic Studies \\
\hline Manuscript ID & 11-20-BHS-1541.R2 \\
\hline Manuscript Type: & Original Article \\
\hline Keywords: & women, poets, Spain, Latin America, transnational, avant-garde \\
\hline Abstract: & $\begin{array}{l}\text { Abstract } \\
\text { 'The fatal fact of the woman writer' is a phrase coined by the Argentine } \\
\text { author Alberto Pineta in the late } 1920 \text { s, a time marked by women's } \\
\text { growing presence in the cultural sphere. On both sides of the Atlantic, } \\
\text { women expressed an acute interest in the avant-garde literary culture } \\
\text { and faced similar challenges in their attempt to negotiate their place in } \\
\text { the literary field. By considering Spanish-speaking women as mediators } \\
\text { across cultural and geographical borders, this study seeks to move } \\
\text { beyond the concepts of 'centre' and 'periphery' in order to rethink the } \\
\text { avant-garde as a transnational and multifaceted phenomenon. To } \\
\text { explore the intertwined trajectories of Gabriela Mistral, Alfonsina Storni } \\
\text { and Ernestina de Champourcín, this study examines their literary } \\
\text { activities in Madrid and provides a comparative analysis of the avant- } \\
\text { garde themes that recur in their poetry. Special focus is set on the } \\
\text { transnational processes that shaped their work and allowed them to } \\
\text { assert their identity as female writers and poets. } \\
\text { Key words: women, writers, poets, avant-garde, transnational, } \\
\text { perspectives } \\
\text { Resumen }\end{array}$ \\
\hline
\end{tabular}


1

2

3

4

5

6

7

8

9

10

11

12

13

14

15

16

17

18

19

20

21

22

23

24

25

26

27

28

29

30

31

32

33

34

35

36

37

38

39

40

41

42

43

44

45

46

47

48

49

50

51

52

53

54

55

56

57

58

59

60 transnacionales

\section{SCHOLARONE \\ Manuscripts}




\title{
'The Fatal Fact of the Woman Writer': Transnational Encounters in the Avant-Garde Scene of Interwar Spain
}

\author{
Christina Bezari (Ghent University) \\ [This work is funded by the BOF under the grant agreement number: BOF.PDO.2020.0011.01]
}

\section{Introduction}

In 1929, the Argentine author Alberto Pineta described a gathering of the vanguard group Martín Fierro in Buenos Aires and highlighted the captivating presence of the avant-garde poetess Norah Lange: 'Her grace, sensibility, and creative talent caused those present to accept without protest the fatal fact of the woman writer' (Pineta in Unruh 2006: 1). Pineta's observation on the central role of Lange in one of Argentina's most important literary groups is followed by a reluctant acceptance of a 'fatal fact' that came to dominate public debate in the early decades of the twentieth century. This 'fatal fact' can otherwise be described as a cultural shift that allowed women to be perceived as agents of change and not as mere objects of contemplation. While this shift became more evident with the increasing participation of women in the labour market, their presence in the avant-garde literary scene was often met with suspicion and discontent on both sides of the Atlantic.

In Spain, the influential philosopher José Ortega y Gasset lamented the fact that women wished to participate in the literary life of the country and expressed his conviction that men are in charge of building the new Spain: 'nuestro tiempo no es sólo tiempo de juventud, sino de juventud masculina... La mocedad masculina se afirma a sí misma, se entrega a sus gustos y apetitos, a sus ejercicios y preferencias [...]' ([1927] 1958: 205). In a similar vein, Miguel de Unamuno argued that literary language is predominantly male and that women should use domestic language to express their thoughts in private: 'El escribir una mujer para el público en lengua literaria masculina es algo así como ponerse los pantalones. Porque la lengua literaria es "pantalónica" [...] en lo que la mujer sobresale como escritora es en las cartas privadas, donde la lengua y estilo son más domésticos' (1958: 682). In the Latin American context, the Argentine author Eduardo González Lanuza proclaimed in the preface to his prose collection Aquelarre that this was an opportune time for a 'masculine book' of 'vigorous' energy leaving no room for 'sentimentalism' (1927: 8). These examples show that although women's presence in the public sphere started to grow, literary culture continued to perceive itself as masculine. This led women to occupy an uncomfortable and ambiguous position within the new cultural space shaped by the avant-garde movements of the interwar period. Both in Spain and in Latin America women expressed an acute interest in the emerging avant-garde scene and faced similar challenges in their attempt to negotiate their place within the culture industry.

But how did women poets of the avant-garde enter in negotiations with their male counterparts and what spaces did they use to legitimise their intellectual authority? How did they manage to assert their identity and writing persona in a cultural sphere that regarded their presence as unwelcome or unusual? What were the specific themes that they addressed in their poetry and how do these themes reflect the avant-garde culture of the 1920s and 1930s? The 
present study seeks to address these questions by examining the intertwined trajectories of three female poets from Chile, Argentina and Spain: Gabriela Mistral (1889-1957), Alfonsina Storni (1892-1938) and Ernestina de Champourcín (1905-1999). These women crossed paths on numerous occasions. They frequented the same literary circles in Madrid, read each other's work and held a correspondence. But most importantly, they negotiated their intellectual identities in a male-dominated cultural sphere and they displayed a unique awareness of the challenges that modernity posed to literary women. To shed light on the transnational influences that shaped their work, this study relies on a comparative analysis of their literary activities and of the themes that recur in their poetry. This approach aims to show that cross-cultural exchanges taking place in avant-garde circles allowed women poets to expand their network, find their place in the literary world and develop a poetic style that challenged traditional gender roles.

\section{'Decentring the Avant-Garde': Women's Participation in the Literary Scene of Interwar Spain (1918-1936).}

Recent studies have highlighted the need to rethink the avant-garde as an aesthetic and cultural project that manifested itself in various locations. In the past two decades, scholars have attempted to move beyond the socio-political concepts of 'centre' and 'periphery' in order to find new ways of 'decentring the avant-garde' (Bäckström and Hjartarson 2014: 9). Bäckström and Hjartarson's primary objective has been to map the avant-garde as a transnational phenomenon by examining different facets of avant-garde aesthetics in regions that are traditionally depicted as peripheral. In a similar vein, Diana Roig-Sanz and Reine Meylaerts have posited that the dichotomy between 'innovative' centres and 'imitative' peripheries hinders us from following 'processes of cultural exchange as they develop' (2018: 3). To overcome this dichotomy, Harding and Rouse have proposed a shift from a Eurocentric to a transnational conception of the avant-garde (2006: 2). This shift recognises that 'the sites of artistic innovation associated with the avant-garde are often sites of unacknowledged cultural hybridity and negotiation' (2006: 2). To recognise these sites of experimentation and hybridity, Harding and Rouse have questioned the premise that the avant-garde was tied to a Eurocentric cultural sensibility. In their view, previous studies have privileged a Eurocentric approach to the avant-garde and have not acknowledged the impact of non-European writers and movements. To move beyond this approach, this study considers the avant-garde as a transnational and heterogeneous movement and examines the exchanges between Spanish and Latin American women poets.

The participation of women in the avant-garde movements of the interwar period has gained critical attention in the past three decades. The ground-breaking work of Susan Suleiman has pointed to a double exclusion from the literary canon and from the historical avant-gardes. According to Suleiman, 'the place of women, and of avant-garde movements, has traditionally been situated away from the centre, “on the fringe", in the margins' (1990: 14). The difference is, however, that 'avant-garde movements have willfully chosen their marginal position', while women have often been relegated to the margins against their will (Suleiman 1990: 14). Suleiman's acute analysis of the woman/avant-garde/marginality trope has shown that women's 
marginal position has also become a source of self-legitimation and strength in a period when being marginal also meant being avant-garde.

In the Spanish-speaking context, the innovative studies of Susan Kirkpatrick and Vicky Unruh have highlighted that the interwar period was a pivotal moment in women's development as writers and poets. Kirkpatrick argues that during this time Spain witnessed the rise of flapper culture, which allowed women to distance themselves from their domestic roles and embrace avant-garde aesthetics (2003: 26). In the same vein, women across Latin America 'undertook a critical dialogue with modern male writers [and] embraced a vanguard conception of artistic work as a dynamic cultural engagement' (Unruh 2006: 3). Both of these studies show that the modernisation of women's roles in society urged them to claim a more prominent position in the literary scene. With regard to the themes that they employed, Candelas Gala underscores the avant-garde emphasis on dynamism, the various technological advances and the presence of industrial symbols such as motors and engines (2011: 162, 168). Biruté Ciplijauskaité emphasises the importance of metaphors and evocative images used to describe moments of silence, illusion and loss (1999: 161). In an early study of surrealist imagery in women's poetry, Catherine Bellver argues that the 'assimilation of vanguard motifs' did not hinder women from using a distinctive voice to express their state of mind (1991: 301). These critical works have shed new light on the writing strategies that female poets used to create their poetic personas and express their aesthetic vision.

While previous studies have made substantial progress in recovering the memory of forgotten female poets and placing them within a national setting, this study takes a different approach by examining women's work from a comparative perspective and within a transnational framework. More specifically, it encourages a dialogue across geographical and cultural boundaries and offers the opportunity to explore women's multifaceted contributions to an increasingly transnational movement. The female protagonists of this study defied the stereotype of the 'virtuous woman', positioned themselves in the public sphere as agents of change and built bridges of communication with their counterparts across the Atlantic. As Pura Fernández has shown in a ground-breaking study of cultural networks between Spanish and Latin American women writers, the creation of a transnational space was a crucial step in establishing international collaborations and developing a sense of identity (2015: 13). Building on this approach, I will examine women's literary collaborations and exchanges in tandem with the themes they used in their poetry and in relation to the impact they had in and beyond national borders.

Gabriela Mistral, Alfonsina Storni and Ernestina de Champourcín all played a prominent role in the literary life of their native countries but they also travelled abroad, came into contact with foreign authors and presented their work across national borders. Long before she became the first Latin American author to receive a Nobel Prize in Literature in 1945, Mistral was a school teacher in Santiago de Chile and in rural areas across the country. Her first steps as a poet began with publications in local periodicals such as El Coquimbo and La Voz de Elqui, although she was later invited to publish her work in renowned literary magazines such as Rubén Darío's Elegancias and Pedro Prado's avant-garde quarterly Los Diez. Oscillating between the avant-gardes and Latin American modernismo, Mistral's poetry is known for its emphasis on the autochthonous, its mystical search for union and its social awareness. While her early poetry collections Desolación (1922) and Ternura (1924) are more contemplative, her 
later collection Tala (1938) displays strong affinities with the avant-garde movements of the time. As we shall see in what follows, the years that she spent in Madrid and the connections that she established with her Spanish counterparts greatly enhanced the reception of her work outside the Americas.

In 1924, Mistral visited Spain for the first time after finishing a mission in Mexico, where she worked on a reform of the national education system along with the Mexican Minister of Education José Vasconcelos. In December 1924, the PEN Club in Madrid organised a tribute dinner at the renowned restaurant Lhardy to celebrate her poetry and offered her the critical acclaim that she needed to start her international career. During the dinner, Enrique Díez Canedo underscored the value of her poetry and the new perspectives that it offers: 'Necesitamos voces como la suya, Gabriela, que nos animen a concertar la ronda infinita que pase por las calles agitadas y por las campiñas estremecidas' (Caballé 1993: 236). Between 1933 and 1935, Mistral resided in Madrid where she served as Consul for the Chilean government and formed friendships with Spanish writers and intellectuals such as Carmen Conde, Consuelo Bergés, Clemencia Miró, Antonio Oliver Belmás, Guillermo de Torre, Miguel de Unamuno, Benjamín Jarnés and Victoria Kent. By maintaining this circle of close friends and admirers, she was able to integrate into the cultural life of the Spanish capital and become one of its most prominent literary figures.

In 1926, Mistral met with Alfonsina Storni in Argentina and dedicated an essay to her in the newspaper El Mercurio de Chile (Horan and Meyer 2003: 63). By that time, Storni was active in the cultural scene of Buenos Aires. Along with her partner Horacio Quiroga, she attended the meetings of the avant-garde groups Nosotros and Anaconda in the early 1920s, both of which were mainly open to male writers. Storni also frequented the literary circle $L a$ Peña, which was founded in 1926 and hosted notable figures such as Luigi Pirandello and Josephine Baker. In the late 1920s and early 1930s, she became member of the Signo group that welcomed the Italian futurist poet Massimo Bontempelli and the Spanish vanguard poets Ramón Gómez de la Serna and Federico García Lorca (Unruh 2006: 31). She also collaborated with some of the most prominent literary magazines in Argentina such as La Nación and Nosotros. Storni visited Europe twice in 1930 and 1932. Her first trip to Madrid was followed by immediate success, as seen in Luz Morales's article in the Spanish magazine El Sol: 'Alfonsina Storni pertenece a esa sardana sonora de femenino eco resonante, que enguirnalda a América [...] Pero hay un acento apasionado, facetas de sinceridad absolutamente originales, inéditas, no oídas' (Astrada de Terzaga 1967: 139). The Spanish writers Enrique Díez Canedo and Cristóbal de Castro shared this enthusiasm for Storni's work and saw her as a promising figure in the flourishing avant-garde scene of the time.

Though a decade and a half younger than her Latin American friends, Ernestina de Champourcín was quick to find a place in the literary life of Madrid. During the 1920s, she became close to influential poets and writers such as Jorge Guillén and Huberto Pérez de la Ossa who introduced her to the literary circles of the Spanish capital and encouraged her to publish her poems and essays in avant-garde magazines such as La Gaceta Literaria and La Época. Champourcín was also an important figure of the Lyceum Club Femenino (1926-1937), a literary institution that encouraged the presence of women in the cultural scene and promoted 
the circulation of their works. ${ }^{1}$ Thanks to her mediation, both Gabriela Mistral and Alfonsina Storni visited the Lyceum, met with its female members and used it as a space to exchange ideas and give lectures in 1928 and 1930 respectively. By that time, the two Latin American women were seen as literary models for younger female poets who wished to find a place in the literary world. In her letters to her friend Carmen Conde, Champourcín expressed a profound admiration for both Mistral and Storni, whose poetry became a source of inspiration for her own work:

Conocí a Gabriela Mistral hace tres años y sus versos me impresionaron mucho, tanto que trascendieron a los míos aún inéditos y balbucientes (Champourcín in Fernández Urtasun 2007: 61) [...] Con Gabriela hablamos de ti largamente, la veo mucho y nuestras charlas se prolongan mañanas enteras (Champourcín in Fernández Urtasun 2007: 382).

Alfonsina Storni me ha tomado un cariño loco y Blanca de la Vega ha incluido mi poema 'Amor' en el programa de su primer recital [...] Hemos quedado grandes amigas. Iré una tarde a tomar el té con ella sola y a hablar de poesía. Me pareció muy comprensiva e inteligente (Champourcín in Fernández Urtasun 2007: 345-346).

These passages reveal a strong connection between Champourcín and her two friends from Chile and Argentina. Her enthusiastic descriptions of their meetings in Madrid are marked by a spirit of mutual admiration and camaraderie, which allowed Champourcín to expand her cultural horizons. In her private correspondence, she often presented Storni as 'intelligent' and 'cosmopolitan' and described Mistral as 'a great teacher' and an example to be followed by younger generations of poets (Fernández Urtasun 2007: 345, 46). These descriptions illustrate the importance of literary friendships, which helped young female poets to expand their social circle, exchange ideas and fashion their poetic identity. To forge her identity, Champourcín portrayed herself as a cosmopolitan poet with a profound knowledge of foreign literatures and great aspirations for the future. ${ }^{2}$ She also expressed a keen interest in the vanguard tendencies of her time, as she admitted in an interview with Arturo del Villar: '[... ] en La Gaceta Literaria hice mis pinitos entre ultraístas y surrealistas, en dos o tres poemas que publiqué en sus páginas'

\footnotetext{
${ }^{1}$ The Lyceum Club Femenino was founded in 1926 based on a similar institution that existed in London. Its first director, María de Maeztu, published an article on the $5^{\text {th }}$ of November 1926 in the newspaper El Heraldo de Madrid to explain the reasons why such an institution was vital for women's intellectual development: 'Se intenta facilitar a las mujeres españolas, recluidas hasta ahora en sus casas, al mutuo conocimiento y la mutua ayuda. Queremos suscitar un movimiento de fraternidad femenina; que las mujeres colaboren y se auxilien... Por ejemplo: asistir a muchachas que en cualquier campo de la actividad estén pugnando por abrirse camino y luchen con los obstáculos con que siempre se tropieza al empezar a trabajar' (Maeztu in González Naranjo 2015: 721).

${ }^{2}$ Champourcín's mother was born in Montevideo and her father often travelled to Uruguay and brought her books. This is how she became familiar with the work of the Uruguayan poets Juana de Ibarbourou and Delmira Agustini. In addition to Uruguayan and Latin American poetry, Champourcín became interested in French literature and read the works of Víctor Hugo, Alphonse de Lamartine, Alfred de Musset, Alfred de Vigny and Paul Verlaine. In a letter to her friend Carmen Conde, she described her participation in an international congress that took place in Toledo and boasted over her cosmopolitan lifestyle: 'El domingo fui a Toledo con los congresistas de la "Unión pro Sociedad de Naciones". Éramos doscientos y almorzamos en el claustro de San Juan de los Reyes. Me divertí en grande. Hice la conquista de un húngaro, dos belgas y un búlgaro. ¡Soy cosmopolita!...’ (Champourcín in Fernández Urtasun 2007: 291).
} 
(Champourcín in Dougherty 2009: 662). In addition to her contributions to local newspapers, Champourcín's publications in foreign magazines allowed her to receive international exposure at a time when she was permanently residing in Madrid. In 1929, she started a collaboration with the Argentine magazine Síntesis in which she published an essay entitled '3 Proyecciones'. In this essay, she defended young female poets, who became interested in the avant-garde and who wished to find avenues to publish their poetry: 'Nuestras escritoras más jóvenes llegan adscritas por afinidad de ideas y temperamento, al grupo de las vanguardistas [...] Volante en mano, sin faldas que recojan el polvo del camino, sin imitar a nadie, lograrán conquistar su poesía' (Champourcín 1929: 332). This description highlights women's connection to the avant-garde and illustrates the authenticity of their ideas.

Through her articles in the press and her literary activities in Madrid, Champourcín tried to encourage transnational exchanges between Spanish and Latin American women of letters. By the late 1920s, literary salons and institutions like the Lyceum Club Femenino acquired great importance for female authors and poets who wished to make a living out of their writing despite their country of origin. Women's professionalisation was nevertheless a difficult task due to lack of resources or lack of a professional network. To improve their chances of finding a patron or building new collaborations with an editor, women of the interwar period attended cafés, tertulias and salons, which became important venues for both aspiring and established poets and artists:

In those cafés the divine and the human were discussed, fortunes were made and contracts for millions were signed, in the back, on a marble table. Novels were written and important theatre companies were formed... The hours went by as tomorrow's history was being made; dreams were fabricated, created and impossible revolutions and untenable governments were projected (Ontañón in Mangini 2010: 26).

For female poets who began to experiment with avant-garde ideas, salons and other literary institutions became places of legitimation as they offered the possibility to recite poetry in front of large audiences. Mistral's recital of poetry in the Lyceum Club Femenino took place in 1928 and was followed by immediate success. Following Mistral's appearance in the Lyceum, its director, María de Maeztu, invited a number of Latin American writers to give lectures, enter into dialogue with their European counterparts and participate in the vibrant cultural life of the Spanish capital. Among the female writers and artists who were hosted by the Lyceum Club Femenino were the Argentine Alfonsina Storni, Victoria Ocampo and Norah Borges, the Uruguayan Delmira Agustini, the Cuban Lydia Cabrera and the Venezuelan María Teresa de la Parra (Mangini 2006: 128). These women shared their writings and engaged in conversations about the future of poetry. The spirit of camaraderie and collaboration among them created an outpouring of publications, events and literary gatherings that were fiercely criticised by avantgarde male writers such as Ernesto Giménez Caballero, José Díaz Femández and Jacinto Benavente. ${ }^{3}$ As Champourcín recalls, the slightest hint of women's independence as writers and

\footnotetext{
${ }^{3}$ Ernesto Giménez Caballero made a parody of the the Lyceum Club Femenino in his journal La Gaceta Literaria, which was one of the most important platforms for avant-poets poets turning away from Gongorism and embracing the surrealist movement. In his avant-garde novel La venus mecánica (1929), José Díaz Femández also mocked the Lyceum by highlighting that it was a 'club of spouses', who were married to illustrious male poets. Jacinto
} 
thinkers was systematically dismissed by journalists in the press: 'a los periodistas les parecía muy raro que una mujer escribiera... Es divertidísimo porque no comentan nuestra poesía, lo que comentan es que es una mujer' (Champourcín in Bellver 1995: 71). Champourcín's contemporary María Teresa León makes a similar remark about women's participation in literary salons: 'En los salones de la calle de las Infantas se conspiraba entre conferencias y tazas de té. Aquella insólita independencia mujeril fue atacada rabiosamente' (1970: 514). Despite these critiques, however, women's presence in the cultural sphere continued to grow and their impact on the literary scene of the time became more visible.

While women used literary institutions and salons to legitimise their intellectual authority and consolidate their authorial personas, male poets in Madrid gathered around their own cultural centres. One such centre was the Residencia de Estudiantes, which was founded in 1910 with the objective to foster an intellectual environment for Spain's avant-garde poets and artists including Federico García Lorca, José Moreno Villa, Salvador Dalí and Luis Buñuel. Although scholars have often studied the Lyceum Club Femenino in contrast to the Residencia de Estudiantes (Mangini 2006; González Naranjo 2015), members of both institutions expressed sympathy for each other's cause and negotiated their place in the literary world. It is telling that Alberto Jiménez Fraud, the first director of the Residencia de Estudiantes, spoke generously of female poets who gathered around Madrid's Lyceum and described them as a group of ladies with great social influence: 'una junta de damas de gran influencia social' (Pérez-Villanueva Tovar 2010: 188). Ernestina de Champourcín also described her visit to the Residencia de Estudiantes and her positive interaction with the renowned poet and painter José Moreno Villa: 'Antes de dejar la Residencia, Moreno Villa nos llevó a sus habitaciones y nos enseñó sus cuadros. Algunos muy interesantes, yo creo que son plasmaciones de sueños. Me encanta el ambiente de la Residencia, es acogedor y tan amplio' (Champourcín in Fernández Urtasun 2007: 256). As this passage suggests, friendships between members of the Lyceum and members of the Residencia were possible and often facilitated women's access to the cultural sphere. Though not always welcomed by their counterparts, female poets made decisive steps to build bridges of communication and legitimise their position in the literary field.

Women's literary activities in interwar Madrid cannot be seen as isolated from their poetry. While the Lyceum Club Femenino became one of the most prominent literary institutions for upcoming female authors, not all of its members embraced avant-garde aesthetics. In reality, only a few women who were associated with the Lyceum incorporated avant-garde elements in their poetry and showed a genuine interest in the avant-garde movements flourishing in Europe and Latin America. Among these women, we can mention Mistral, Storni and Champourcín as well as Concha Méndez, Rosa Chacel and the Spanish painters Maruja Mallo, Margarita Manso and Ángeles Santos. These women positioned themselves in the cultural sphere as figures of modernity and constructed their public personas based on progressive ideas. While a lot of the themes that we encounter in the poetry of Mistral, Storni and Champourcín display a strong affinity with the avant-garde movements of the time, there have been constructive discussions as to whether their work was truly a part of the avantgarde. Gwen Kirkpatrick has argued that Storni 'was associated with a "middlebrow" public

Benavente who had been invited to give a lecture at the Lyceum, famously replied that he did not wish to talk to 'silly and crazy women': 'A mí no me gusta hablar a tontas y a locas' (Benavente in Johnson 2003: 28). 
and considered to be "outside of the vanguard" because of [her] use of conventional poetic techniques, like rhyme, and meter, in much of her work' (1995: 97). Astrada de Terzaga, however, has pointed to two different stages that characterise Storni's poetry: '[...] su primera época, en el sentido temporal, es posmodernista y la segunda vanguardista' (1967: 129). Indeed, Storni's later collections Mundo de siete pozos (1934) and Mascarilla y trébol (1937) break with rhyme and adopt free verse. Both collections belong to her avant-garde period and initiate a rupture that was unique among the poets of her generation.

Torre and Hutt have also expressed doubts as to whether Mistral's poetry was influenced by avant-garde movements: 'In contrast to the vanguardias, Mistral's work comes across as formally outdated, even simplistic, inasmuch as she gives preference to thematic social engagement over formal experimentation and rupture' (2012: 18). Other scholars have challenged this view by emphasising the novelty of her language that resonates with her passion for social commitment: 'Mistral did participate in avant-garde construction -in her choice of topics, in the ways in which she approached the processes of renewing language, and through the numerous poetic masks with which she subverted the poetic authority' (Agosín 2003: xviii). Similar to her Latin American friends, Champourcín became interested in the new literary movements that emerged during the interwar period. Her collections Ahora (1928), La voz en el viento (1931) and Cántico inútil (1936) all bear the influence of avant-garde aesthetics and adopt avant-garde modes of expression. Nevertheless, as Lorraine Hanley has shown, her later turn to spirituality and mysticism has overshadowed some of her earlier works (2008: 164). During the years of her exile, Champourcín's poems are marked by her faith in God, while her 'spiritual transformation becomes a continuous theme in her poetry' (2008: 165).

Despite their contested place in the ranks of the avant-garde Mistral, Storni and Champourcín engaged in a critical dialogue with their male counterparts, published their poetry in vanguard magazines and attended literary gatherings and salons where avant-garde ideas were discussed. Their originality is found in the diverse influences that shaped their poetry and in the ways that these influences shaped and enriched their authorial personas. As we will see in what follows, all three of them made use of avant-garde themes to express their aesthetic values and push for innovation and originality. A closer look at their poetry will allow us to examine the transnational aspects of their writing and the intellectual needs that brought them together. While the influence of the avant-garde is dominant, it is nevertheless not exclusive, for their poetry was multifaceted and remained open to different styles and tendencies. A comparative study of the poems that they published during the interwar period will reveal a common interest in modern society and the redefinition of its values. Through the dynamic use of imagery and metaphor as well as through their contributions to high-circulation magazines, Mistral, Storni and Champourcín attempted to redefine their social roles and situate themselves within a changing environment where the place of women was strongly criticised and contested.

\section{Avant-Garde Themes in Women's Poetry}

During the interwar period, the emergence of the woman poet seemed inevitable. But the 'fatal fact' of women's participation in the literary field was also part of the revolutionary character of the 'felices años veinte' (the roaring twenties). During that period, women embodied the transition from 'being' to 'becoming', capturing the energy of avant-garde culture and 
incorporating new themes in their poetry. Reluctance to accept women's presence in the literary sphere would seem as a refusal to adhere to the spirit of the times and to the possibilities that emerged from modern popular culture. In Spain, women poets who experimented with avantgarde themes dared 'to discover themselves as creative subjects' and defied traditional conceptions of womanhood 'by creating self-asserting female personae' (Bellver 2001: 217). A similar tendency prevailed in the work of Latin American women poets, who made a decisive intervention in public life by 'redefining central aspects of Latin American modernity' and creating a 'rupture with earlier aesthetics' (Torre and Hutt 2012: $26 \&$ 36). Though scholars have mainly focused on women's efforts to undermine conventional patriarchal models, Mistral, Storni and Champourcín also addressed a number of opposing themes: alienation, anxiety, dehumanisation and crisis, on the one hand, and a feeling of enthusiasm, energy, vitality and dynamism on the other.

Writing at a time of artistic innovation and intellectual ferment allowed Spanish and Latin American women poets to draw on different sources and experiment with avant-garde ideas. Pleasure, enthusiasm and a need for vindication became important points of reference in their poetry, as women vanguardists sought to overcome social conventions and declare their freedom. As seen earlier in this study, Storni was presented in Champourcín's letters as a close friend and a literary model for younger generations. In their poetry, both women contemplate modern society and its spirit of exuberance while engaging in a critique of traditional values and mores. In her poem Cuadrados y ángulos, Storni evokes a feeling of existential anxiety by reflecting on the homogenisation of people's lives and comparing 'square houses' to people's 'square souls':

\author{
Casas enfiladas, casas enfiladas, \\ casas enfiladas, \\ cuadrados, cuadrados, cuadrados, \\ casas enfiladas. \\ Las gentes ya tienen el alma cuadrada, \\ ideas en fila \\ y ángulo en la espalda; \\ yo misma he vertido \\ ayer una lágrima, \\ Dios mío, cuadrada.
}

(El dulce daño, 1918).

In this poem, Storni adopts a geometrical approach to convey a sense of monotony associated with the old Euclidean ways. Houses as well as ideas are shaped like squares and they are arranged in single lines. The verses of the poem mimic the lines of houses and one identical verse comes after another. The people who are confined in these houses have square souls and follow the same ideas. Storni's criticism of social conformity is intertwined with a fear of alienation that becomes apparent in the final verse, where the poetic persona becomes painfully aware of her own conformity. But the speaker's 'square tears' are also a way of expressing discomfort with the Euclidean model in geometric shapes. The speaker regrets the tendency of 
remaining attached to old models and shapes, as this attachment limits her freedom and her pursuit of happiness. Champourcín adopts a similar approach in her poem Calle, which was published in July 1930 in the Spanish magazine Bolivar:
$[\ldots]$
Cal y sueño. Las paredes
de tan blancas hacen daño.
Blancura insomne, delirio
de castidades a salvo.
Todos caminan sin huella.
En la esquivez de los pasos
enhebra el sol las puntadas
que los muros rechazaron.

(Bolivar, 15/7/1930).

The contrast between the words 'cal y sueño' (lime and dream) creates a surrealist image in which dreams crush against the concrete matter of the lime. Champourcín uses the image of a white wall to create a feeling of cosmic alienation. The white colour hurts the eyes and leads to insomnia. Just like the lines of endless houses in Storni's poem, the white walls are used here as a symbol of monotony and repetition. The white colour is also a symbol of chastity, which is nevertheless fleeting and dubious. While lonely and isolated people are alienated from the cosmic weaving of the sun, they also experience alienation as they are imprisoned within the chastity of walls. People's 'elusive steps' in the poem Calle can be seen in relation to the 'square souls' described in the poem Cuadrados y ángulos. Both poems offer a compelling interpretation of the modern psyche by exploring the fear of isolation and the longing for plenitude, wholeness and joy. Visual imagery and a sense of limited space are used to reinforce the feeling of cosmic alienation, which is presented as a fundamental part of the human experience. This feeling is a constitutive element of the avant-garde literary culture of the time and occupies a central place in the poetry of Storni and Champourcín. Mistral also addresses the feeling of cosmic alienation in her poem La extranjera:

Habla con dejo de sus mares bárbaros, con no sé qué algas y no sé qué arenas; reza oración a dios sin bulto y peso, envejecida como si muriera.

En huerto nuestro que nos hizo extraño, ha puesto cactus y zarpadas hierbas.

Alienta del resuello del desierto y ha amado con pasión de que blanquea, que nunca cuenta y que si nos contase sería como el mapa de otra estrella. [...] 
(Tala, 1938)

This poem is marked by a profound sense of otherness, which alienates the poetic subject from its autochthonous identity. This is a recurring theme in Mistral's collection Tala, which is influenced by an 'endogenous avant-garde' that attempts to valorise indigenous cultures (Concha 1987: 99). In La extranjera, the poetic subject experiences a personal crisis deriving from a feeling of cosmic alienation. The speaker belongs to another star, speaks a different language and embraces another cosmic realm that introduces new elements in the context of conventional expectations. Despite efforts to follow the path to self-realisation, the modern world provides limited opportunities for transcendence.

In her collection Mundo de Siete Pozos (1934), Storni includes a section of poems that address the theme of alienation in the context of the modern metropolis. This section entitled Motivos de ciudad contains the poem Calle, a title that is identical to the one used earlier by Champourcín. In this poem, Storni employs the image of high grey walls to reflect on a distressing feeling of isolation that is similar to the one evoked by Mistral and Champourcín. All three of them highlight the absence of transcendence and evoke the dehumanising aspects of modern society. In Storni's poem Calle, there is a contrast between the downward direction to the catacombs of the human soul and the upward ladder that symbolises immanence and transcendence. Walking down the hallway, the speaker hesitates to opt for the chthonic earth or find refuge in transcendence:

Entre altos paredones grises.

A cada momento

la boca oscura de las puertas,

los tubos de los zaguanes,

trampas conductoras

a las catacumbas humanas.

¿No hay un calofrío

en los zaguanes?

¿Un poco de terror

en la blancura ascendente

de una escalera?

[...]

(Mundo de Siete Pozos, 1934).

The image of the wall also emerges in Storni's poem Selvas de ciudad in which she compares the city to a human jungle that is hard to navigate: 'Son muy anchas las paredes;/ muy espesos los techos'. Either grey or white, the walls hinder the speaker from embracing a sense of adventure that seems to be central in the poem. Similarly, Mistral's poem La desasida expresses the solitude of the poetic subject, which is longing to break free from existential limitations: 'Pude no volver y he vuelto./ De nuevo hay muro a mi espalda' $(2008,46)$. In this poem, the wall is used as a symbol of the heavy burden that has fallen upon the poetic subject. The decision to return has been as painful as a wall that prohibits the speaker from embracing action. A 
similar idea is expressed in the poem La dichosa, in which Mistral uses the image of a black wall to criticise the lack of liberation and transcendence:'El muro es negro de tiempo/ el liquen del umbral, sordo' (2008: 56). Yet, the possibility of freedom arises when the speaker decides to break with social conventions: 'ahora vivimos libres/ del tiempo de ojos celosos' (2008: 56).

Mistral, Storni and Champourcín all evoke the image of the wall to emphasise a feeling of alienation that grows stronger within the urban context. The city obliges the poetic subjects to face sturdy and impenetrable walls, which are often the cause of hopelessness and despair. Empty rooms and white or black colours are used to evoke images of deficiency and absence, which are typical of the avant-garde movement. These images are linked to a feeling of uncertainty that is expressed in manifold ways. Both in Storni's poem Palabras degolladas and in Mistral's Árbol muerto, the poetic subject finds itself in an unstable environment and struggles to find its roots. The urban landscape undergoes constant changes and the words are now 'strangled', 'drained' and 'deformed'. In both of these poems, the speaker appears uncertain of the future and uses a subjective tone to express his/her inner struggle. Uncertainty is also key to Champourcín's La voz en el viento, in which the speaker expresses an inner voice through a scream. This poem evokes the energetic and modern spirit of the avant-garde, as the female speaker attempts to proclaim chance, fill the emptiness with her voice and exalt the modern world of uncertainties:

\section{$[\ldots]$}

Galoparé adherida

al filo de los tiempos

y colmará mi grito

vacíos insondados.

¡Erguida sobre el lomo

de todo lo inestable,

derrumbaré certezas

en nombre del azar!

(La voz en el viento, 1931).

In this poem, the poetic subject is galloping at the edge of time while contemplating the emptiness of space. Both time and space are important notions in the avant-garde movement and are used in this poem to convey a sense of instability. The poetic subject embraces the unstable aspects of life and sees fortuity as a means of liberation. Breaking free from the urban environment allows the speaker to create a personal space of expression that goes against the values of stability and materiality. Storni and Mistral engage with their poetic subjects in similar ways. Their poetry challenges social conventions and calls for a re-evaluation of traditional values and a redefinition of modern society. While anxiety, materiality, and conformity are seen as key characteristics of urban life, their poetry seeks to move away from this vision and juxtaposes the beauty of nature to the alienation of the city. Mistral's poem Cordillera is representative of this tendency. In this poem, Mistral uses evocative images of the Andes mountains to highlight the beautiful and terrifying power of mother nature: 'Donde son valles, 
son dulzuras;/ donde repechas, das el ansia;/ donde azurea el altiplano/ es la anchura de la alabanza' (Mistral [1938] 2005: 67). The mountain-range lifts up the indigenous American and functions as a source of inspiration and guidance among the Andean nations. The 'cordillera' is also presented as the poet's mother offering comfort and protection to its child. In this way, the poem underscores the superiority of nature over the mundanity of the city.

Mistral, Storni and Champourcín made use of evocative images and expressive language to highlight the creative and innovative dimensions of their craft. Although their poetry and personal trajectories cannot be reduced to a single poetic mission, they nevertheless shared a critical attitude towards the 'superficial subjectivism' of previous generations of poets and juxtaposed their 'audacious and enthusiastic' vision of future poetry (Champourcín 1929: 331, 332). In examining the different aspects of their work, it is possible to observe a common interest in the individual and its place in the modern world as well as a common critique of modern society. By introducing poetic subjects that are alienated from themselves, from other humans and from nature, the three women poets of this study underscored the importance of self-reflection in an increasingly dehumanising and materialistic world. But they also opened new avenues in the field of the avant-garde by challenging stereotypes connected to gender and embracing the dynamic and unconventional spirit of the roaring twenties.

\section{Conclusion}

This study has attempted to demonstrate that Spanish-speaking women played a crucial role in the avant-garde scene of the interwar period and that they sought to transcend national boundaries by disseminating their ideas abroad and building collaborations with their foreign counterparts. Their participation in the public sphere as poets, salon attendees and contributors to avant-garde magazines allows us to examine their work from a transnational perspective and in a comparative framework. By joining literary circles and institutions like the Lyceum Club Femenino, Mistral, Storni and Champourcín had the opportunity to engage in a transnational dialogue and present their work in front of an international audience. In addition to these activities, their collaborations with the foreign press offered greater visibility in the international arena and allowed them to position themselves as advocates of social change. A comparative study of their poetry has also highlighted the existence of avant-garde themes that break with traditional patterns and question aspects of modern life such as materiality, alienation and conformity. These themes enhance the transnational character of their poetry and reveal common concerns for the future.

In exploring the intertwined trajectories of Mistral, Storni and Champourcín, this study has sought to capture the complexities of women's participation in the ranks of the avant-garde. While existing definitions of vanguard poetry 'have tended to emphasise aesthetic aspects proper to the European and Anglo-American contexts' (Torre and Hutt 2012: 23), this study has focused on expanding the geographical scope of the avant-garde to include Spanish and Latin American contributions. In so doing, it has questioned women's peripheral position in the literary field and the double exclusion that they suffered for being women and for being Southern. Despite the challenges they faced, Mistral, Storni and Champourcín acted as cultural mediators beyond their immediate sphere of influence both through their literary activities and 
through their poetry. Seen as a 'fatal fact' or as a long-awaited necessity, their intervention in the public sphere sought to challenge the limits of avant-garde culture and rethink its mission.

\section{WORKS CITED}

Agosín, Marjorie, 2003. Gabriela Mistral: The Audacious Traveler (Athens: Ohio University Press).

Astrada de Terzaga, Etelvina, 1967. 'Figura y significación de Alfonsina Storni', Cuadernos hispanoamericanos, 211: 127-144.

Bäckström, Per and Benedikt Hjartarson eds. 2014. Decentring the Avant-Garde (Amsterdam/New York: Rodopi).

Bellver, Catherine, 2001. Absence and Presence: Spanish Women Poets of the Twenties and Thirties (Lewisburg: Bucknell UP).

Bellver, Catherine, 1995. ‘Conversación con Ernestina de Champourcín’, Ojáncano, 10: 68-77.

Bellver, Catherine, 1991. 'Concha Méndez's El Personaje Presentido and its Vanguard Counterparts', Hispanic Journal, 12 (2): 291-303.

Caballé, Ana, 1993. 'Gabriela Mistral en Madrid', Anales de literatura hispanoamericana, 22: 231-246.

Champourcín, Ernestina de, 1991. 'Bolívar', in Poesía a través del tiempo, prologued by José Angel Ascunce Arrieta (Barcelona: Anthropos).

Champourcín, Ernestina de, 1931. La voz en el viento (Madrid: Compañía General de Artes Gráficas).

Champourcín, Ernestina de, 1929. ‘3 Proyecciones’, Síntesis, 30/11/1929: 329-335.

Ciplijauskaité, Biruté, 1999. De signos y significaciones. Juegos con la vanguardia: poetas del '27 (Barcelona: Anthropos Editorial).

Concha, Jaime, 1987. Gabriela Mistral (Madrid: Júcar).

Dougherty, Dru, 2009. 'Una poética del zigzagueo: Ernestina de Champourcín (1926-1936)', Hispania, 92 (4): 653-663. 
Fernández, Pura coord. 2015. No hay nación para este sexo. La Re(d)pública transatlántica de las Letras: escritoras españolas y latinoamericanas (1824-1936). (Madrid/Frankfurt: Iberoamericana-Vervuert).

Fernández Urtasun, Rosa ed. 2007. Ernestina de Champourcín \& Carmen Conde: Epistolario (1927-1995) (Madrid: Castalia).

Gala, Candelas, 2011. Poetry, Physics, and Painting in Twentieth-Century Spain (New York: Palgrave Macmillan).

González Lanuza, Eduardo, 1927. Aquelarre (Buenos Aires: Samet).

González Naranjo, Rocío, 2015. 'Ilustres tontas y locas : el Lyceum Club de Madrid, todo un ejemplo de solidaridad femenina', in Locas, escritoras y personajes femeninos cuestionando las normas, XII Congreso Internacional del Grupo de Investigación Escritoras y Escrituras (Sevilla: Alciber), pp. 721-735.

Hanley, Lorraine D., 2008. God, Exile and the Development of the Poetic Voice in the Poetry of Ernestina de Champourcín (Palo Alto: Stanford University Press).

Harding, James M. and John Rouse eds. 2006. Not the Other Avant-Garde: The Transnational Foundations of Avant-Garde Performance (Ann Arbor: University of Michigan Press).

Horan, Elizabeth and Doris Meyer eds. 2003. This America of Ours: The Letters of Gabriela Mistral and Victoria Ocampo (Austin: University of Texas Press).

Johnson, Roberta, 2003. Gender and Nation in the Spanish Modernist Novel (Nashville: Vanderbilt University Press).

Kirkpatrick, Susan, 2003. Mujer, modernismo y vanguardia en España 1898-1931 (Madrid: Catedra-Feminismos).

Kirkpatrick, Gwen, 1995. 'The Creation of Alfonsina Storni', in A Dream of Light and Shadow. Portraits of Latin American Women Writers, ed. Marjorie Agosin (Albuquerque: University of New Mexico Press), pp. 95-118.

León, María Teresa, 1970. Memoria de la melancolía (Buenos Aires: Editorial Losada).

Mangini, Shirley, 2010. Maruja Mallo and The Spanish Avant-Garde (London: Routledge).

Mangini, Shirley, 2006. 'El Lyceum Club de Madrid un refugio feminista en una capital hostil', Asparkía, 17: 125-140. 
Mistral, Gabriela, 2008. Madwomen: The 'Locas mujeres'. Poems of Gabriela Mistral, ed. Randall Couch (Chicago: University of Chicago Press).

Mistral, Gabriela, 2005. Tala (Santiago: Pehuén Editores).

Ortega y Gasset, José, 1958. La rebelión de las masas (Madrid: Espasa-Calpe).

Pérez-Villanueva Tovar, Isabel, 2010. 'La cátedra de la Residencia de Estudiantes: vocación internacional y proyecto europeísta', Boletín de la Institución Libre de Enseñanza, 78-80: 181198.

Pineta, Alberto, 1962. Verde memoria (Buenos Aires: Antonio Zamora).

Roig-Sanz, Diana and Reine Meylaerts eds. 2018. Literary Translation and Cultural Mediators in 'Peripheral' Cultures. Customs Officers or Smugglers? (Cham: Palgrave Macmillan).

Storni, Alfonsina, 1918. El dulce daño (Buenos Aires: Cooperativa Ed. 'Buenos Aires').

Storni, Alfonsina, 1934. Mundo de Siete Pozos (Buenos Aires: Editorial Tor).

Suleiman, Susan Rubin, 1990. Subversive Intent: Gender, Politics, and the Avant-garde (Cambridge/Massachusetts: Harvard University Press).

Torre, Osvaldo de la, and Claudia Cabello Hutt, 2012. "Another "Waste Land": Gabriela Mistral in 1922', Modernist Cultures, 7 (1): 15-39.

Unamuno, Miguel de, 1958. Obras Completas. Tomo VIII (Madrid: A. Aguado).

Unruh, Vicky, 2006. Performing Women and Modern Literary Culture in Latin America (Austin: University of Texas Press). 